\title{
HADHANAH IN THE CONCEPT OF COMPILATION OF ISLAMIC LAW AND LAW
}

\author{
Salsabila Firdausia ${ }^{1}$
}

\begin{abstract}
KHI states that hadanah for a child who is not mumayyiz or not yet 12 (twelve) years old is the right of his mother. The basis of the 12-year law is not found in the Al- Qur'an, hadits and fiqh literature. Therefore, the author conducts research to determine the hadanah in the concept of KHI and Undang-undang. This type of research is yuridis normatif. The source of this research data is secondary data. Based on the results of the study, the hadhanah rights remain with both parents even if the parents are divorced. It is mentioned in the KHI, UU Perkawinan and UU Perlindungan Anak that giving love to a child is an obligation attached to the parents towards the child from the time the child is in the womb until the end of his life.
\end{abstract}

\section{Keywords: Hadhanah, Divorce, Children}

\section{The Introduction}

Divorce is often chosen as the right way to solve a problem that does not end in a marriage. In fact, divorce is not always the right solution as a way out. Divorce will have new legal consequences, one of which is the legal consequences of child custody.

Divorce is not an obstacle for a child to obtain custody of himself and his parents, one thing that is a great fear for a child is parental divorce, when divorce occurs the child will be the main victim. Child rearing is a need or necessity for the benefit of the child himself, so that even if both parents have a bond or are divorced, the child still deserves the attention of both parents (Purwaningsih, 2014).

In article 105 letter (a) Compilation of Islamic Law based on Inpres No.1 of 1991 (hereinafter referred to as KHI) states "The care of a child who is not mumayyiz or not yet 12 (twelve) years is the right of the mother". The author assumes that this article is still multi-interpretation, especially on the word "Mumayyiz", because it is good in the Qur'an nor hadiths and figh literatures do not explicitly state how old a person can actually be said to have been "Mumayyiz". In addition, the article uses the word "or", this can be interpreted as a legal choice regarding the age limit of a person is said to have been "Mumayyiz". Even if the words "Mumayyiz" and "or" are omitted in the article so that it becomes "Raising a child under the age of 12 (twelve) years is the right of the mother", then the question is whether the legal basis so that the age limit of 12 (twelve) years is said to be a child has mumayyiz. Based on the above questions and assumptions, the author is interested in doing research.

\section{Research Methods}

This research is descriptive analysis, with a type of yuridis normatif research. The data source in this study uses secondary data. Secondary data

1 Institut Agama Islam Negeri Tulungagung, Email: firdausia58@gmail.com 
in this study comes from library research research (Library Research) obtained from primary, secondary and tertiary legal materials.

The data collection technique in legal research is normative, so the data collection technique used in this study is a library study. Library study is a method of data collection conducted by reading legal materials that are relevant to the topic of discussion or problem to be studied.

\section{Discussion and Results}

Divorce is not something that couples want, because divorce can have a negative impact on them and their children. Divorce is a burden for children because it can have a physical or psychological impact. Therefore, parents who want to divorce should consider this. If divorce is unavoidable, then parents should give understanding to the child so as to reduce the negative impact on the child (Ramadhani \& Krisnani, 2019).

As for the negative impact on the child is to be silent, humble, naughty, low learning achievement and feel lost. However, not all divorce cases have a negative impact on children. In most cases divorce is not too negative. That is, most divorce cases have a negative impact on the development of the child's soul and affect the child's educational process (Yusuf, 2014).

Divorce cases often occur among the community even though in positive law and Islamic law has complicated the divorce process. Parental divorce can have a negative impact on the child. It is unimaginable how many children are disturbed to grow and develop when there are parenting issues.

Child custody disputes are sometimes a protracted polemic, both in the case of child custody established by a Court decision falling on one of the parents or in the case of the Court's decision stating child custody is done jointly by both parents. It is this struggle that will eventually lead to actions that can affect the mindset and psychological of the child.

The custody of the child usually falls on the mother, but not a few rights foster child falls on his father. Although child custody falls on the mother, but child support remains an obligation of the father. In many cases a child living with a mother rarely gets a proper alimony with a court decision, some even no longer earn a living from his father (Munawir, 2016).

A mother is more entitled to child custody. This matter because a mother has ainstinct more appropriateto care for and educate her child and her patience in facing the problems of children's lives is higher than the patience of a man (father) (Saimima, 2014).

Child protection is the embodiment of the existence of justice in a society, as contained in the provisions of article 2 of Undang-undang No. 23 of 2002 on Child Protection (hereinafter referred to as the UU Perlindungan Anak) which states: "The implementation of child protection is based on Pancasila and is based on the UUD 1945 as well as the basic principles of the Convention on the Rights of the Child including: non-discrimination; best interests of the child; the right to life, survival and development; appreciation of the child's opinion ". Thus, child protection is pursued in various areas of state and community life. Child protection activities bring legal consequences, both in relation to written law and unwritten law. Based on the UU Perlindungan Anak, the rights and obligations of children are also mentioned. In this law, the protection of the child is very important, however 
the situation of the parents, they both must still think about the welfare of the child in this world and in the hereafter.

\section{The concept of hadhanah in the Compilation of Islamic Law}

Hadhanah agreed upon by figh scholars states that in principle the law of caring for and educating children is an obligation for both parents. Because the child is still young and has not mumayyiz will be easily influenced by things that may not beaccepted by the child. So there is a need for guidance, education, care and good care by their parents. This is in accordance with the word of God in QS. At-Tahrim: 6.

KHI regulates the parental authority over the child by using the term "child care" found in articles 98 to 112 . By dividing, article 107 to article 112 regulates guardianship, while about hadhanah is regulated in article 98 and 105.

KHI articles on hadhanah assert that material and non-material care obligations are 2 inseparable. KHI also explained about the duties of both parents that must be done for the sake of their children even with the situation that they are divorced. The child who is not mumayiz is still raised by his mother, while financing is the responsibility of his father. The power of the parents after the divorce against the child, can be invested by the Religious Court, and the Religious Court can decide to whom the parental authority over the child is overthrown. The decision of the Religious Court in deciding the matter alone will precede and provide assurance on the welfare of the child's life.

In the case of hadanah that once occurred in the Palembang Religious Court, the judge did not specify who was given the hadanah right. Though in this case the child is mumayyiz and has chosen one of both parents. The jury gives the verdict in the interests of the child and the welfare of the parents. Thus, no party feels more entitled to one child and the child also feels unrestrained due to the restriction of his movement to communicate with parents who are not designated as hadanah rights holders (Huzaimah, 2013).

The scholars of Madhhab Hanafi argue that those who are entitled to custody are women who are close relatives of the child. Like an aunt from the mother or from the father (uncle) or grandmother from the child. It is likely that they are more serious and diligent in caring for the child, because of the lineage and kinship with the child. This is in line with article $156 \mathrm{KHI}$.

In the case of mummayiz limitations set out in the Law and seeing events in the field, such provisions become imperative or absolute. If the child feels uncomfortable living with his mother after the divorce of both parents because his mother does not care or because his mother has left him since childhood when the child is still a baby. So the judge can set aside the article and make a decision according to the interests of the child and not contrary to Islamic law. For a hadhin or caregiver who deals with the interests of the child he is raising is the adequacy and competence that requires certain conditions. If the conditions are not met as a whole, then the ability of a hadhin to perform hadhanah or his upbringing falls. The condition of a hadhin is to be healthy, mature, capable in educating, trustworthy and virtuous, Muslim (Shiddieqy, 2011), the situation of unmarried women who are married, and independent (Syabiq, 1983). 
Hadhin must be a Muslim because according to Islam, a small Muslim child cannot be brought up by a non-Muslim caregiver. This is because hadanah is a guardian problem. Allah does not allow Believers under the care of infidels (Jauhari, 2012).

\section{The concept of hadhanah in law}

According to Arif Gosita, legal certainty is pursued for the continuation of child protection activities and to prevent malpractice that brings undesirable negative consequences in the implementation of protection (Gultom, 2006). The policy of the implementation of child protection is in accordance with philosophical, ethical and juridical principles.

The Philosophical Basis can be interpreted as Pancasila as the basis of activities in various areas of family life, community, state and nation as well as the philosophical basis of the implementation of child protection. The ethical basis of the implementation of child protection must be in accordance with the ethics of the relevant profession, to prevent deviant behavior in the exercise of authority, power, and power in the implementation of child protection. The legal basis is the implementation of child protection must be based on the 1945 Constitution and various other applicable laws and regulations. The application of this juris prudence must be integrative, that is, the application of integrated legislation concerning various relevant areas of law.

Child protection can be done directly, that is by doing child protection activities directly. In Law No. 4 of 1979 on Child Welfare in Chapter IV of Article 11 it is written that child welfare should also be sought by the government in the form of coaching, prevention, development and rehabilitation. For example, protecting children from threats by building, educating or accompanying. Child protection can also be done indirectly, that is, activities that are indirectly directed at the child, in a way that others do or are involved in child protection efforts.

UU Perlindungan Anak states in Article 1 paragraph 2 that child protection is all activities to ensure and protect children and their rights to live, grow, develop, and participate, optimally in accordance with the dignity and dignity of humanity, and to be protected from violence and discrimination.

Article 8 states that every child is entitled to health and social security services in accordance with their physical, mental, spiritual, and social needs. Article 13 explains that every child during the care of a parent, guardian, or any other person responsible for care, is entitled to protection from treatment: Discrimination; Exploitation, both economic and sexual; Disposal; Cruelty, violence and persecution; Injustice; and other misconduct; In the case of parents, guardians or babysitters performing all forms of treatment as referred to in paragraph 1 , the perpetrator is subject to the imposition of punishment.

Article 14 of the Child Protection Act states that "Every child has the right to be cared for by his or her parents, unless there are valid reasons and / or legal rules indicating that the separation is in the best interests of the child and is a final consideration". In the explanation it is stated that, "Separation referred to in this provision does not eliminate the child's relationship with his parents". So even if there is a legal provision on the 
custody of the child falls on one of the parents, then the other parent has no right to forbid meeting with their child. From the point of view of Islamic law, KHI regulates child custody or hadhanah post-divorce with a criteria of 12 years, because at this age the child is considered to have reached puberty. So a child who is not yet 12 years old will be under the control of his mother. After more than 12 years the child is allowed to decide for himself who will be raised by whom. But still, the number 12 years can not be a definite focus to think about the benefits and harms.

As for Article 26 it is mentioned again about the obligation of parents in the protection of their children. While Article 36 states that in the case of the appointed guardian it turns out that later did not speak of committing a legal act or abusing his power as a guardian, then his guardian status is revoked and appointed by others as a guardian through a court order. In the case of a deceased guardian, another person is appointed as a guardian through a court order.

States and governments have a duty and responsibility to respect and guarantee the rights of every child regardless of race, religion, race, class, gender, ethnicity, culture, language, legal status of child, birth order, physical condition, and / or mental condition of child. As a legal basis on the obligation of parents in raising and caring for children is also mentioned in Law Number 1 of 1974 on Marriage (which is later written by the Marriage Act) in article 45 paragraphs 1 and 2 which mentions the rights and obligations between children and parents. In this case both parents must take care of and educate their children as best they can until the child is married or able to stand alone. Article 41 of the Marriage Law states that parents who are divorced still have the obligation to care for and educate their children. This is done solely based on the interests of the child. In the event of a dispute over the control of a child, then the court may issue a decision. The cost of care and education that a child needs will be borne by his father. However, if the father is unable to give the obligation, then the court can determine that the mother bears the costs.

Article 49 paragraph (2) of the UU Perkawinan, namely: "Even if the parents are deprived of their power, they are still obliged to provide maintenance costs to the child". Based on the provisions of this article, then the obligation to nurture and care for the child is imposed on both parents even if the parents have separated. For the amount of costs determined according to the ability of the parents.

Regarding child custody due to divorce, most scholars, including the scholars of Madzhab Syafi'i agree that, the right to care for a child is the responsibility of the mother, as long as the mother is not married and will lose the right of child care for the mother who remarries with someone else. but in reality there are still many children who are abandoned, unmanaged and even many acts of sexual violence experienced by children due to the lack of parental support for their children. The government created a service unit that is responsible for assisting children whose rights are lost due to the divorce of their parents, namely ULT PSAI (Integrated Child Social Protection Integrated Services Unit). ULT PSAI is responsible for assisting children who are victims of an action against the law that results in the loss of their rights. However, the treatment carried out by ULT PSAI is still 
passive, that is, waiting for a complaint from the victim. ULT PSAI has become a form of government attention to the problems that arise in society.

\section{Conclusion}

Results of the discussion on the conception of KHI and the potential law on hadhanah or custody of children are fixed to both parents even in the case of divorced parents. Divorce will still have an psychological impact on the child, at least it can be minimized by still guaranteeing the rights of the child. Still provide alimony, supervision, education and support that is almost the same as that obtained by children in the whole family. It is mentioned in the KHI, UU Perkawinan and UU Perlindungan Anak that giving love to a child is an obligation attached to the parents to the child from the child being in the womb until the end of his life.

\section{References}

Ash Shiddieqy. T. M. Hasbi. (2011). Hukum antar golongan dalam fiqh Islam, Bulan Bintang.

Gultom, Maidin. (2006). Perlindungan hukum terhadap anak; Dalam sistem peradilan pidana anak di Indonesia. RefikaAditama.

Huzaimah, Arne. (2013). Problematika penyelesaian perkara hadanah di Pengadilan Agama Kelas 1 A Palembang. Nurani: Jurnal Kajian Syariah dan Masyarakat, 13(1), 15-36. https://doi.org/10.19109/nurani.v13i1.114

Jauhari, Iman. (2012). Kewajiban nafkah hadanah dan rada'ah terhadap anak di Indonesia. Asy-Syir'ah: Jurnal Ilmu Syari'ah dan Hukum, 46(2), 501-526.

Munawir. (2016). Implementasi eksekusi Putusan Pengadilan Agama Ponorogo terhadap hak hadanah anak (Kajian terhadap putusanputusan cerai gugat di PA Ponorogo tahun 2014). Al-Manahij: Jurnal Kajian Hukum Islam, 10(1), 119-132. https://doi.org/10.24090/mnh.v10i1.920

Purwaningsih, Prihatini. (2014). Hak pemeliharaan atas anak (hadhanah) akibat perceraian ditinjau dari hukum positif. Yustisi, 1(2), 55-65.

Ramadhani, Putri Erika. \& Krisnani, Hetty. (2019). Analisis dampak perceraian orang tua terhadap anak remaja. Focus: Jurnal Pekerjaan Sosial, 2(1), 109-119. https://doi.org/10.24198/focus.v2i1.23126

Sabiq, Sayyid. (1980). Fiqh assunnah. PT al-Ma'arif.

Saimima, Salma. (2014). Ibu penderita skizofrenia dan dampaknya terhadap hadanah dalam perspektif Islam. Tahkim: Jurnal Hukum dan Syariah, 10(2), 34-52. http://dx.doi.org/10.33477/thk.v10i2.1264

Yusuf, M. (2014). Dampak perceraian orang tua terhadap anak. Jurnal AlBayan: Media Kajian dan Pengembangan Ilmu Dakwah, 20(1), 33-44. http://dx.doi.org/10.22373/albayan.v20i29.112 